\title{
DNA Sequencing for AXIN 2 (SNP 7591 and 7224837) Gene Polymorphisms in Non-Syndromic Cleft Lip and/or Cleft Palate in the Local Population
}

\author{
Vishnuvardhan $V^{1}$, Manjunath Hegde ${ }^{2}$, Dinesh M. R ${ }^{3}$, R. M. Dharma ${ }^{4}$ \\ ${ }^{1}$ Final year resident, Department of Orthodontics, DAPM R.V. Dental College, Rajiv Gandhi University of Health Sciences, Bengaluru - \\ 560078, India
}

${ }^{2}$ Reader, Department of Orthodontics, DAPM R.V. Dental College, Rajiv Gandhi University of Health Sciences, Bengaluru -560078, India

${ }^{3}$ Principal, DAPM R.V. Dental College, Rajiv Gandhi University of Health Sciences, Bengaluru -560078, India

${ }^{4}$ Professor and Head, Department of Orthodontics DAPM R.V. Dental College, Rajiv Gandhi University of Health Sciences

Bengaluru -560078 , India

\begin{abstract}
Introduction: The aim of this study was to evaluate the association of AXIN2 gene variants rs 7591 and rs 7224837 with non-syndromic cleft lip and palate. Materials and Methods: Blood samples of 30 subjects with NSCLP and 30 unrelated controls were used for the study. The extracted DNA samples were subjected to Polymerase chain reaction in which amplification of the selected gene segments was done; later these amplified products were subjected to DNA sequencing. Results: This study suggests that the likelihood of Non-syndromic cleft lip and palate is higher in subjects having TT $(p<0.001)$ \& AT (p=0.03) genotype for AXIN2 gene variant rs 7591 and $A G(p=0.01)$ genotype for AXIN2 gene variant rs 7224837 . Conclusion: The result suggests that AXIN2 gene variant rs 7591 and AXIN2 gene variant rs 7224837 can be considered as genetic markers for Non syndromic cleft lip and palate in local population.
\end{abstract}

Keywords: Non-syndromic Cleft Lip and Palate, AXIN2, AXIN2 gene variant rs7591 and AXIN2 gene variant rs7224837

\section{Introduction}

Isolated, non-syndromic cleft lip with or without cleft palate represents one of the most common human birth defects with significant medical, psychological, social and economic ramifications.[41]

Mammalian palatogenesis is a complex process involving highly regulated interactions between epithelial and mesenchymal cells of the palate to permit correct positioning of the palatal shelves and subsequent fusion of the palatal shelves which require matrix metalloproteinases [26]

Recent success in genome-wide linkage and association studies has identified novel loci significantly associated with Cleft lip and palate [10]. Researchers are currently striving to identify the etiologic variants at these novel loci to understand the developmental disturbances leading to Cleft lip palate, and this knowledge should eventually result in improved prevention, treatment and prognosis for individuals with this condition.

As orthodontists are intimately and ardently involved in the successful therapeutic management of the patients affected with cleft lip with or without cleft palate and its associated tooth anomalies, it becomes essential that they keep current knowledge on the etiology of these conditions. It is therefore necessary to study about these genetic variations to elaborate our understanding of the genetic control in various craniofacial determinants. The Axin2 mutation displays enhanced expansion of osteoprogenitors, accelerated ossification, stimulated expression of osteogenic markers and increased mineralization.

In the present study, the focus of interest is to study the relationship of Axin2 gene variants (rs7591 and rs7224837) with Non Syndromic Cleft Lip/Palate in our population. This will help us in understanding the etiology of Non syndromic Cleft Lip / Palate so as to predict its occurrence and also to target the gene at the molecular level for correction of such problems.

\section{Materials and Methods}

$2 \mathrm{ml}$ venous blood samples from 30 cases with non syndromic cleft lip with / without palate and 30 unrelated controls who visited Department of Orthodontics and Dentofacial Orthopedics, D.A.P.M.R.V.Dental College, were taken after the written informed consent. These were divided into two groups: Group A: Thirty subjects with Non syndromic cleft lip/ palate (P1- P30) Group B: Thirty controls (C1- C30)

Inclusion criteria for Group-A subjects: The presence of Non syndromic cleft lip/ palate on clinical examination. Exclusion criteria for Group-A subjects: Cleft lip/palate associated with any:-History of developmental disabilities, including learning disabilities and attention deficits, hearing impairment, and speech deficits or abnormalities may be the first indication of an underlying syndromic genetic disorder; Family history of orofacial clefts and related conditions, including any additional major associated anomalies (e.g., cardiac defects and eye and brain anomalies);History of maternal illnesses; Medication (e.g., anticonvulsants and retinoic acid derivatives), vitamin (before and after

\section{Volume 6 Issue 1, January 2017




\section{International Journal of Science and Research (IJSR) \\ ISSN (Online): 2319-7064 \\ Index Copernicus Value (2015): 78.96 | Impact Factor (2015): 6.391}

conception) during pregnancy; Tobacco use, Smoking during Pregnancy; Ethanol intake during pregnancy.

The polymorphism in Axin 2 gene variants rs 7591 and rs 7224837 were detected using the Polymerase Chain Reaction (PCR) test followed by DNA Sequencing.

Automated DNA sequencing procedure was selected for the sequencing of DNA where each nucleotide was labelled with fluorescent dyes. Thus when the DNA fragments were placed on the electrophoresis gel and passed through a laser beam, the DNA sequence was detected more precisely and accurately on a electropherogram unlike other sequencing techniques.

\section{Methodology}

The methodology consisted of five steps:

Step 1: Collection and storage of blood samples,

Step 2: Extraction of Genomic DNA,

Step 3: Column purification of Genomic DNA,

Step 4: Polymerase Chain Reaction Test (PCR),

Step 5: DNA sequencing (fig 1)

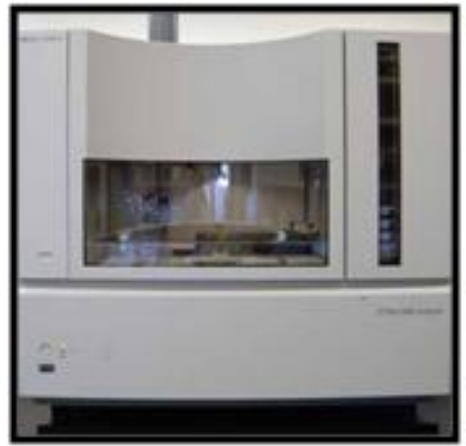

Figure 1: ABI sanger DNA sequencer

\section{Statistical Methods}

$\mathrm{Z}$ test has been used to find the significance of association of Axin 2( rs 7591 and rs 7224837) gene polymorphism with non-syndromic cleft lip and palate.

$\mathrm{Z}$ - test: It can be applied for qualitative as well as quantitative data. Here it was applied to test the difference between two proportions (cases and controls).
Z-test for proportions formula:

$$
\operatorname{SEDp}=\sqrt{\widehat{\mathrm{P}}\left(1-\mathrm{P}^{\wedge}\right)(1 / \mathrm{n} 1+1 / \mathrm{n} 2)} \text { and } \mathrm{P}=\frac{\mathrm{X} 1+\mathrm{X} 2}{\mathrm{n} 1+\mathrm{n} 2}
$$

$\mathrm{p} 1$, proportion $1=\mathrm{x} 1 / \mathrm{n} 1$

$\mathrm{p} 2$, proportion $2=\mathrm{x} 2 / \mathrm{n} 2$

$\mathrm{x} 1$ =number of cases with the 3 genotypes of each gene.

$\mathrm{x} 2$ =number of controls with the 3 genotypes of each gene.

$\mathrm{n} 1=$ total number of cases

$\mathrm{n} 2=$ total number of controls

\section{Statistical Interpretation}

Strongly significant $\mathrm{p} \leq 0.001 * * *$

Significant $\mathrm{p} \leq 0.05^{* *}$

Not significant $\mathrm{p}>0.05^{*}$

Statistical software: The Statistical software namely SPSS 11.0 and Systat 8.0 were used for the analysis of the data and Microsoft word and Excel have been used to generate graphs, tables etc.

\section{Results}

In the present study, the relationship between AXIN2 (rs 7591) and AXIN2 (rs 7224837)gene variants with cleft lip with or without cleft palate was evaluated in 60 subjects consisting of group A (P1-P30) as cases and group $\mathrm{B}(\mathrm{C} 1$ $\mathrm{C} 30$ ) as controls using polymerase chain reaction(PCR) test followed by DNA sequencing.

Results for AXIN2 rs 7591 variants: For AXIN2 (rs 7591) three genotype can be possible:

\begin{tabular}{|l|l|}
\hline T/T & HOMOZYGOUS MUTANT ALLELE \\
\hline $\mathrm{A} / \mathrm{T}$ & HETEROZYGOUS MUTANT ALLELE \\
\hline $\mathrm{A} / \mathrm{A}$ & NORMAL HOMOZYGOUS ALLELE \\
\hline
\end{tabular}

In group A

- 16 out of 30 cases showed the presence of TT genotype.

- 11 out of 30 cases showed the presence of AT genotype.

- 3 out of 30 cases showed the presence of AA genotype.

In group B

- 2 out of 30 controls showed the presence of TT genotype.

- 4 out of 30 controls showed the presence of AT genotype.

- 24 out of 30 controls showed the presence of AA genotype.(graph 1)

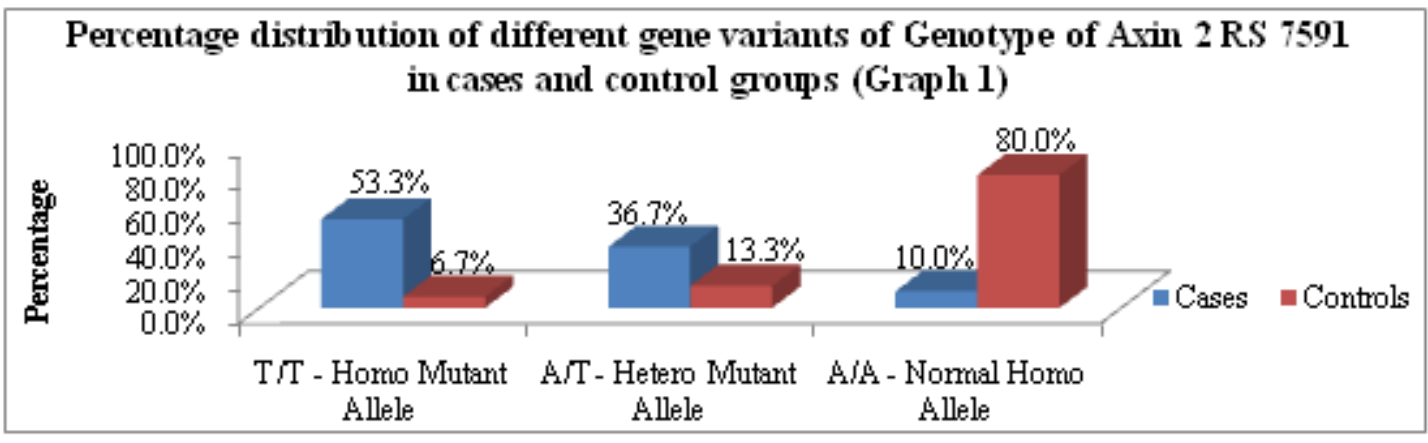

Volume 6 Issue 1, January 2017 www.ijsr.net 


\section{International Journal of Science and Research (IJSR) \\ ISSN (Online): 2319-7064}

Index Copernicus Value (2015): 78.96 | Impact Factor (2015): 6.391

- AA genotype was found to be highly statistically significant with the controls (GROUP B $)(p=0.001)$

- TT genotype was found to be highly significant with the cases (GROUP A ) $(\mathrm{p}=0.001)$

- AT genotype was found to be statistically significant with the cases (GROUP A) $(\mathrm{p}=0.03)$ (as shown in table 1)

Table 1: The table denotes the statistical significance of the genotype when cases and controls are compared using z-test

\begin{tabular}{|c|c|c|c|c|c|c|c|}
\hline $\begin{array}{c}\text { Genotype } \\
\text { of Axin2 } \\
\text { rs 7591 } \\
\begin{array}{c}\text { Gene } \\
\text { Variant }\end{array}\end{array}$ & $\mathrm{n}$ & $\%$ & $\mathrm{n}$ & $\%$ & $\begin{array}{c}\text { Cases } \\
\text { in } \\
\text { Prop }\end{array}$ & $\mathrm{Z}$ & P-Value \\
\hline $\mathrm{T} / \mathrm{T}$ & 16 & 53.3 & 2 & 6.7 & 0.47 & 3.888 & $<0.001^{* *}$ \\
\hline $\mathrm{A} / \mathrm{T}$ & 11 & 36.7 & 4 & 13.3 & 0.24 & 2.147 & $0.03^{*}$ \\
\hline $\mathrm{A} / \mathrm{T}$ & 3 & 10 & 24 & 80 & -0.70 & -5.450 & $<0.001^{* * *}$ \\
\hline
\end{tabular}

Results for AXIN 2 RS 7224837 variants: For AXIN 2 (rs 7224837) three genotype can be possible

\begin{tabular}{|l|l|}
\hline G/G & HOMOZYGOUS MUTANT ALLELE \\
\hline A/G & HETEROZYGOUS MUTANT ALLELE \\
\hline A/A & NORMAL HOMOZYGOUS ALLELE \\
\hline
\end{tabular}

In group $\mathrm{A}$

- 2 out of 30 cases showed the presence of GG genotype.

- 14 out of 30 cases showed the presence of AG genotype.

- 14 out of 30 cases showed the presence of AA genotype.

In group B

- 0 out of 30 controls showed the presence of GG genotype.

- 5 out of 30 controls showed the presence of AG genotype.

- 25 out of 30 controls showed the presence of AA genotype. (Graph 2)

\section{Percentage distribution of different gene variants of Genotype of Axin 2 rs 7224837 in cases and control groups (Graph 2)}

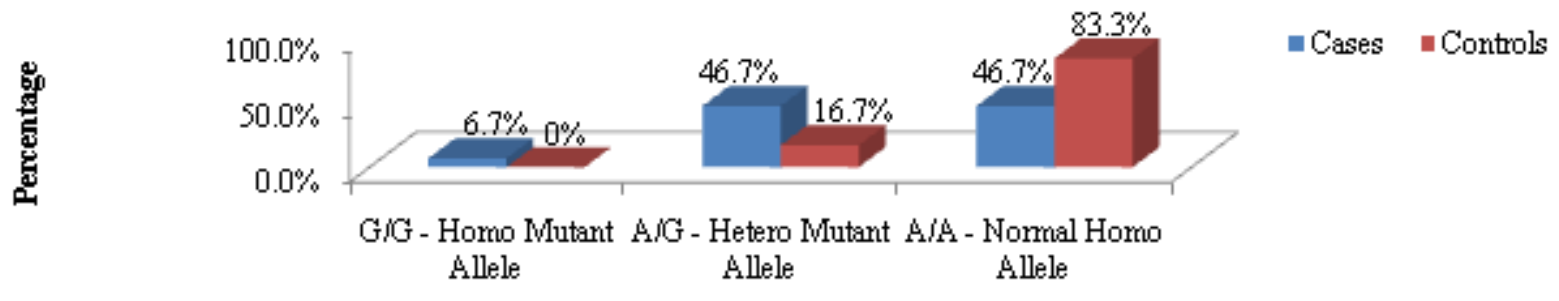

- There were statistically significant difference in AG genotype frequency between cases and controls $(\mathrm{p}=0.14)$

- GG genotype was found to be statistically insignificant with the cases. (GROUP A $)(p=0.14)$

- AA genotype was found to be highly statistically significant with the controls (GROUP B $)(p<0.007)$ (as shown in table 2)

Table 2: The table denotes the statistical significance of the genotype when cases and controls are compared using z-test

\begin{tabular}{|c|c|c|c|c|c|c|c|}
\hline Genotype of & \multicolumn{2}{|c|}{ Cases } & \multicolumn{2}{|c|}{ Controls } & & & \\
\cline { 2 - 7 } $\begin{array}{c}\text { Axin2 rs } \\
7224837\end{array}$ & & & & & & & \\
gene variant & $\mathrm{n}$ & $\%$ & $\mathrm{n}$ & $\%$ & $\begin{array}{l}\text { Difference } \\
\text { Proportion }\end{array}$ & $\mathrm{Z}$ & P-value \\
\hline $\mathrm{G} / \mathrm{G}$ & 2 & 6.7 & 0 & 0 & 0.07 & 1.475 & $0.14^{*}$ \\
\hline $\mathrm{A} / \mathrm{G}$ & 14 & 46.7 & 5 & 16.7 & 0.30 & 2.491 & $0.01^{* *}$ \\
\hline $\mathrm{A} / \mathrm{A}$ & 14 & 46.7 & 25 & 83.3 & -0.33 & 2.708 & $0.007^{* * *}$ \\
\hline
\end{tabular}

\section{Discussion}

Craniofacial morphogenesis is regulated by complex interactions between the surface and neural ectoderms, endoderm paraxial mesoderm and cranial neural crest (Francis 1998).This morphogenetic process is highly dependent on the patterning information of emigrant cranial neural crest cells (Couly et al, 1996).Upon closure of the neural fold, these cells migrate ventro laterally to populate the head and neck regions and give rise to a wide variety of tissues. Majority of craniofacial malformations are caused by defects in these cells. Therefore understanding the mechanisms that control craniofacial development, particularly the cranial neural crest cells and its contribution to various facial tissues and structures, might provide new insights into the molecular basis of these defects in humans. [17]

Studies of orofacial clefting have shown that $\mathrm{CL} / \mathrm{P}$ has complex inheritance patterns as evidenced by a positive family history for clefting in $33 \%$ of the patients, no clearly recognizable mode of inheritance, and reduced penetrance. The relative risk for siblings, defined as the prevalence in siblings of an affected individual divided by the population prevalence, is 40 ; there is a $2-5 \%$ increased risk for offspring of affected individuals and a greater concordance in monozygotic than dizygotic twins, all providing evidence that genetic factors play an etiologic role. Yet, segregation analyses have not conclusively defined the mode of inheritance. Studies have estimated that 3-14 genes interacting multiplicatively may be involved, indicating that $\mathrm{CL} / \mathrm{P}$ is a heterogeneous disorder. [19]

Determining the sequence of bases in DNA has become a major challenge of contemporary biology. DNA sequencing of human and other genome has been the center of interest in the biomedical field over the past several decades and is now leading toward the era of personalized medicine.

During this time, DNA sequencing methods have evolved from the labor intensive slab gel electrophoresis, through automated multicapillary electrophoresis systems using fluorophore labelling with multispectral imaging. DNA sequencing allows the use of four dideoxynucleotide chain terminator, tagged with dyes of different fluorescent emission wavelengths in a single sequencing reaction which 


\section{International Journal of Science and Research (IJSR) \\ ISSN (Online): 2319-7064}

Index Copernicus Value (2015): 78.96 | Impact Factor (2015): 6.391

is depicted by a graph called as Electropherogram and Chromatogram. This graph contains peaks of four different colours which are universally coded for each nucleotide (Thymine-red, Adenine- green, Guanine-black, Cytosineblue). Any change in normal nucleotide sequencing will be shown as different colour peak and if it is homozygous it will be shown as a single peak while if it is heterozygous it will be shown as double peak.

According to the interpretation of the electropherogram and statistical analysis, in our population, AXIN2 gene variant rs7591, showed statistically significant differences in genotype frequencies between cases and controls, with TT $(p<0.001)$ and AT $(p=0.03)$ genotypes found more in cases, with AA genotype $(\mathrm{p}<0.001)$ found more in controls. (Table no.1 and Graph no.1).

According to the interpretation of the electropherogram and statistical analysis, in our population, AXIN2 gene variant rs7224837 showed statistically significant differences in genotype frequencies between cases and controls, with $\mathrm{AG}(\mathrm{p}=0.01)$ genotypes found more in cases, with $\mathrm{AA}(\mathrm{p}=0.007)$ genotype found more in controls. (Table no. 2 and Graph no. 2).

Our study showed a highly significant difference in presence of genotypes in cases and controls in both the AXIN2 gene variants rs 7591(TT and AT) but AXIN2 gene variants rs7224837 showed a significant difference only for AG genotype. Thus the data suggest that the WNT signalling pathway may contribute to as much as $3-5 \%$ of NS CLP and will be a consideration in the clinical management of CL/P [24].

The results of our study are contrary to the study done by Bjork, M.E.Cooper et al (2012) in multiple population, suggesting presence of AXIN2 gene variant 7224837 is strongly associated with cleft lip and palate. The contradictory results are probably due to genetic heterogenecity, incomplete penetrance, limited sample sizes and different study designs.

Gene manipulation can be employed to control the expression of any gene in several orthodontically relevant issues. In turn we may witness the introduction of both preventative and in vivo foetal therapy for these debilitating conditions.

The findings of this study indicate that Axin2 gene variants rs7591 and rs7224837 gene polymorphisms may be one of the genetic markers for cleft lip and palate in our population. Further studies, targeting a large sample size are required for a better insight to assess the complex genetics of Non syndromic cleft lip and palate.

\section{Conclusion}

1) This study indicates that there is a highly significant association between the presence of AXIN2 gene variant rs7591 and a significant association between AXIN2 gene variant rs 7224837 with the incidence of Non syndromic cleft lip and palate.
2) This study suggests that the likelihood of Non syndromic cleft lip and palate is higher in subjects having TT $(p<0.001)$ \& AT $(p=0.03)$ genotype for AXIN2 gene variant rs7591 and $A G(p=0.01)$ genotype for AXIN2 gene variant rs 7224837.

3) This study suggests that the incidence of Non syndromic cleft lip and palate is lesser in subjects having AA $(p<0.001)$ genotype of AXIN2 gene variant rs7591 and $\mathrm{GG}(\mathrm{p}=0.14) \& \mathrm{AA}(\mathrm{p}=0.007)$ genotype of $\mathrm{AXIN} 2$ gene variant rs 7224837.

4) The findings of this study suggest that AXIN2 gene variant rs7591 and rs 7224837 can be considered as genetic markers for Non syndromic cleft lip and palate for our population.

\section{References}

[1] Chung.C.S,Bixler.D, Watanabe.T et al. Segregation Analysis of Cleft Lip with or without Cleft Palate: A Comparison of Danish and Japanese Data.Am J Hum Genet 1986; 39:603-611.

[2] Romitti P, Lidral CA, Munger GR, Hirsch DS, et al. Candidate genes for nonsyndromic cleft lip and palate and maternal cigarette smoking and alcohol consumption. Evaluation of genotype-environment interactions from a population-based case-control study of orofacial clefts. Teratology 1999; 59:39-50.

[3] Vladislav Doln'ik. DNA sequencing by capillary electrophoresis (review). J. Biochem. Biophys Methods .1999; 41:103-119.

[4] François Fagotto, Eek-hoon Jho, Li Zeng, Thomas Kurth et al. Domains of Axin Involved in Protein-Protein Interactions, Wnt Pathway Inhibition, and Intracellular Localization. The Journal of Cell Biology, Volume 145, Number 4, May 1999 741-756.

[5] Loffredo LC, Souza JM, Freitas JA, Mossey PA. Oral clefts and vitamin supplementation Cleft Palate. Craniofac journal.2001; 38(1):76-83.

[6] Masao Furuhashi, Ken yagi, Hideki yamamoto, Yoichi furukawa et al. Axin Facilitates Smad3 Activation in the Transforming Growth Factor b Signaling Pathway. Molecular and Cellular Biology, Aug. 2001, p. 5132 5141.

[7] Mossey PA, Little J. Epidemiology of oral clefts: an international perspective. In: Cleft lip and palate: from origin to treatment. Oxford University Press, (2002). pp. 127-158.

[8] Monsoro-Burq AH, Wang E, Harland R. Msx 1 and Pax3 cooperate to mediate FGF8 and Wnt signals during Xenopus neural crest induction. Mol Cell Biol. 2002; 22(4):1184-1193.

[9] Eek-hoon Jho, Tong Zhang, Claire Domon,Choun-Ki Joo et al. Wnt/-Catenin/Tcf Signaling Induces the Transcription of Axin2, a Negative Regulator of the Signaling Pathway. Molecular and Cellular biology, feb. 2002, p. 1172-1183

[10] Janet Y. Leung, Frank T. Kolligs, Rong Wu, Yali Zhai, Rork Kuick et al. Activation of AXIN2 Expression by Catenin-T Cell Factor. The Journal of Biological Chemistry. Vol. 277, No. 24, Issue of June 14, 2002 pp. 21657-21665.

[11] Marazita Mary, Margaret Cooper et al .Genome Scan for Loci Involved in Cleft Lip With or Without Cleft Palate, 


\section{International Journal of Science and Research (IJSR) \\ ISSN (Online): 2319-7064}

Index Copernicus Value (2015): 78.96 | Impact Factor (2015): 6.391

in Chinese Multiplex Families. Am J Human Genetics 2002; 71:349-364.

[12] SH Blanton, T Bertin, ME Serna, S Stal .Association of chromosomal regions $3 \mathrm{p} 21.2,10 \mathrm{p} 13$, and $16 \mathrm{p} 13.3$ with nonsyndromic cleft lip and palate- American Journal of medical genetics 2004 Feb 15; 125A (1):23-27.

[13] Blanton SH, Bertin T, Patel S, Stal S et al. Non syndromic cleft lip and palate. Four chromosomal regions of interest. American journal of medical genetics.2004; 125 A (1):28-37.

[14] Stanier P and Moore GE. Genetics of cleft lip and palate: Syndromic genes contribute to the incidence of non-syndromic clefts. Human Molecular Genetics 2004; 13(1):73-81.

[15]FK Wong, U Hägg. An update on the aetiology of orofacial clefts. Hong Kong Med J 2004;10: 331-336.

[16] Wen Luo Sheng-Cai Lin .Axin: A Master Scaffold for Multiple Signaling Pathways Neurosignals .Aug 2004; 13:99-113.

[17] Hsiao-Man Ivy Yu, Boris Jerchow, Tzong-Jen Sheu, Bo Liu et al. The role of Axin2 in calvarial morphogenesis and Craniosynostosis .Development. 2005 April ; 132(8): 1995-2005.

[18] Ian V. Chia and Frank Costantini. Mouse Axin and Axin2/Conductin Proteins Are Functionally Equivalent In Vivo. Molecular and Cellular Biology, June 2005, p. 4371-4376.

[19] Andrew C.Lidral and Lina M.Moreno. Progress towards discerning the genetics of cleft lip. Current Opinion in Pediatrics. December 2005; 17(6): 731-739.

[20] Radhakrishna.U, Ratnamala.U, Gaines.M, Beiraghi.S, et al. Genomewide Scan for Nonsyndromic Cleft Lip and Palate in Multigenerational Indian Families Reveals Significant Evidence of Linkage at 13q33.1-34. The American Journal of Human Genetics 2006; 79: 580585.

[21] Liu B, Yu HM, Hsu W. Craniosynostosis caused by Axin2 deficiency is mediated through distinct functions of beta-catenin in proliferation and differentiation. Dev Biol 2007. 301:298-308.

[22] Rajion AZ and Alwi Z. Genetics of cleft lip and palate: A Review. Malaysian Journal of Medical Sciences 2007; 14(1):4-9.

[23] Clyde A. Hutchison. DNA sequencing: bench to bedside and beyond. Nucleic Acids Research 2007; 35(18) : 6227-6237.

[24]Alexandre R.Vieira, Toby G. McHenry, Sandra DaackHirsch et al.Candidate gene/loci studies in cleft lip/palate and dental anomalies finds novel susceptibility genes for clefts. Genet Med 2008:10(9):668-674.

[25]Brett T. Chiquet, Susan H. Blanton, Amber Burt, Deqiong Ma et al. Variation in WNT genes is associated with non-syndromic cleft lip with or without cleft palate Human Molecular Genetics, 2008, Vol. 17, No. 14 2212-2218.

[26] Renato Menezes, Mary Louise Marazita et al. AXIN2, Orofacial Clefts and PositiveFamily History for Cancer. J Am Dent Assoc. 2009 January; 140(1): 80-84.

[27] N Callahan, A Modesto, R Meira, F Seymen et al .Axis Inhibition Protein 2 (AXIN2) Polymorphisms and Tooth Agenesis Arch Oral Biol. 2009 January ; 54(1): 45-49.

[28] Ariadne Letra1, Renato Menezes1, Jose M. Granjeiro and Alexandre R. Vieira. AXIN2and CDH1
Polymorphisms, Tooth Agenesis and Oral Clefts. Birth Defects Res A Clin Mol Teratol. 2009 February; 85(2): 169-173.

[29]Meng L, Bian Z, Torensma R, Von den Hoff JW. Biological mechanisms in palatogenesis and cleft palate. J Dent Res. 2009;88 (1):22-33

[30] Birnbaum S, Ludwig KU, Reutter H, Herms S, Steffens M, Rubini $M$ et al.Key susceptibility locus for nonsyndromic cleft lip with or without cleft palate on chromosome 8q24. Nat Genet. 2009 Apr;41(4):473-7

[31] Barry L. Karger and Andras Guttman.DNA Sequencing by Capillary electrophoresis. 2009 June;30(1): 196-202.

[32] Bryan T. MacDonald, Keiko Tamai, and Xi He .Wnt/ $\beta$ catenin signaling: components, mechanisms, and diseases. Dev Cell. 2009 July; 17(1): 9-26.

[33] Peter Mossey, Julian Little.Addressing the challenges of cleft lip and palate research in India. Indian journal of plastic surgery, 2009 oct; 42: 9-18.

[34] Reddy SG, Reddy RR, Bronkhorst EM, Prasad R, et al. Incidence of cleft Lip and palate in the state of Andhra Pradesh, South India. Indian J Plast Surg 2010;43 :184189.

[35] Mangold E, Ludwig KU, Birnbaum S, Baluardo C, Ferrian M, Herms S, et al. (2010). Genome-wide association study identifies two susceptibility loci for nonsyndromic cleft lip with or without cleft palate. Nat Genet 42:24-26.

[36] Michael J. Dixon, Mary L. Marazita, Terri H. Beaty et al Cleft lip and palate: synthesizing genetic and environmental Influences Nat Rev Genet. 2011 March; 12(3): 167-178.

[37] Yao, Lan Yang, Pei-qiang Li, Hua Wu, Han-bing Xie et al . Association of Wnt3A gene variants with nonsyndromic cleft lip with or without cleft palate in Chinese population. Archieves of Oral biology, 56 ( 201 1 ) $73-78$.

[38] A Mostowska, KK Hozyasz, B Biedziak et al. Genotype and haplotype analysis of WNT genes in non-syndromic cleft lip with or withoutcleft palate European journal of Oral Sci. 2012 Feb;120(1):1-8

[39]A.Letra, B. Bjork, M.E. Cooper, H. Szabo-Rogers, F.W.B. Deleyiannis, L.L. Field et al Association of AXIN2 with Nonsyndromic Oral Clefts in Multiple Populations J Dent Res 2012, 91(5):473-478.

[40] Adrianna Mostowska, Kamil K. Hozyasz,Piotr Wo' jcicki, Agnieszka Lasota et al.Association of DVL2 and AXIN2 Gene Polymorphisms with Cleft Lip with or without Cleft Palate in a Polish Population Birth Defects Research (Part A) (2012) 94:943-950.

[41]Fedik Rahimov,Astanand Jugessur, , Jeffrey C. Murray. Genetics of Nonsyndromic Orofacial Clefts.Cleft palate craniofac J , 2013;50(1):96-103.

[42] Jyotsna Murthy, Venkatesh Babu,L.V.K.S. Bhaskar Clinical and demographic factors associated with cleft lip and palate in South India: a hospital based study. International Journal of Latest Research in Science and Technology 2014 May-June ; 3( 3) : 80-83.

[43] Haque, Alam MK, Basri R. Gene involvement in cleft lip and palate (CLP) patients. Bangladesh Journal of Medical Science 2015 January; 14 (01): 113-116. 


\section{International Journal of Science and Research (IJSR) \\ ISSN (Online): 2319-7064}

Index Copernicus Value (2015): 78.96 | Impact Factor (2015): 6.391

\section{Author Profile}

Dr. Vishnuvardhan is a final year resident in the department of orthodontics at the esteemed institution of DAPM R.V Dental College and hospital Bengaluru (Rajiv Gandhi University of Health Sciences).He has completed the dissertation successfully under the expert guidance of Dr Manjunath Hegde who completed his Masters in SDM Dental College in 2003 and is currently a reader in DAPM R.V Dental College, Dr. M.R. Dinesh (Principal) ${ }^{3}$, Dr. R.M. Dharma( Head of Department) ${ }^{4}$. He has also received a lot of support from Dr.Amarnath (Professor), Dr.Prashanth (Professor), Dr.Akshai (Professor), Dr.Roopak (Reader), Dr.Pramod (Senior lecturer), Dr.Sharmila (Senior lecturer) in the preparation of the dissertation. 